\title{
Sedimentology and geochemistry of saline lakes of the Great Plains
}

\author{
W. M. Last \& T. H. Schweyen \\ Department of Earth Sciences, University of Manitoba, Winnipeg, Manitoba, Canada R3T 2 N2
}

Keywords: saline lakes, Great Plains, geolimnology, sedimentology, geochemistry

\begin{abstract}
Southern Saskatchewan and portions of adjacent Alberta, North Dakota and Montana are occupied by hundreds of saline and hypersaline lakes ranging in size from small prairie potholes (less than $1 \mathrm{~km}^{2}$ ) to relatively large bodies of water (greater than $300 \mathrm{~km}^{2}$ ). From a sedimentological perspective, distinction must be made between two basic types of saline lakes: playas and perennial lakes.

Calcium, sodium and magnesium sulfates, carbonates and bicarbonates form as chemical precipitates in lakes with more concentrated brines. In addition, experimental data suggests mixed layer smectites may form authigenically in some lakes. Clastic sediments in the salt lakes consist mainly of silt and clay-sized quartz, feldspars, carbonates and clay minerals.

The dominant physical and chemical processes which are responsible for and act upon the sediment vary widely, mainly in response to basin morphology and brine chemistry. Eva porative concentration and significant groundwater contributions affect all the saline lakes. However, other processes are different in the two basic types of basins. The playa lakes are influenced by: evaporitic pumping and the formation of efflorescent crusts and intrasedimentary crystals, cyclic wetting and drying, precipitation of highly soluble salt layers, and influx of clastic debris by sheetflood and wind. In contrast, in the permanent lakes, precipitation of sparingly soluble salts occurs due to the interaction of biological activity, seasonal temperature fluctuations and brine mixing. In addition, many of the permanent lakes undergo freeze-out precipitation of very soluble salts under a winter ice cover. Detrital sediments are distributed within the basins by normal lacustrine processes, including shoreline deposition and erosion, turbidity flow and pelagic fallout.
\end{abstract}

\section{Introduction}

In recent years our knowledge of the sediments and sedimentary processes operating in saline lakes has advanced significantly. Generalized quantitative models have begun to emerge that enable geologists to recognize, interpret and predict a given lacustrine depositional sequence (Al-Droubi et al. 1980; Eugster \& Hardie 1978; Hardie et al. 1978). Much of this work has been directed toward lakes occupying closed hydrographic basins within two basic settings: (1) rift valleys, such as the saline lakes of Africa's eastern rift system, and (2) depressions in block-faulted terrains, such as the playas of the Basin and Range province of western United States. In spite of these advances inland salt lakes still represent one of the least studied and understood depositional regimes in sedimentary geology.

The Great Plains of western Canada and northern United States are occupied by hundreds of saline and hypersaline lakes (Fig. 1). These lakes range in size from small prairie potholes less than $1 \mathrm{~km}^{2}$ to relatively large bodies of saline water up to $300 \mathrm{~km}^{2}$. The biological and hydrochemical characteristics of many of these lakes are well documented due to the early contributions of Rawson \& Moore 


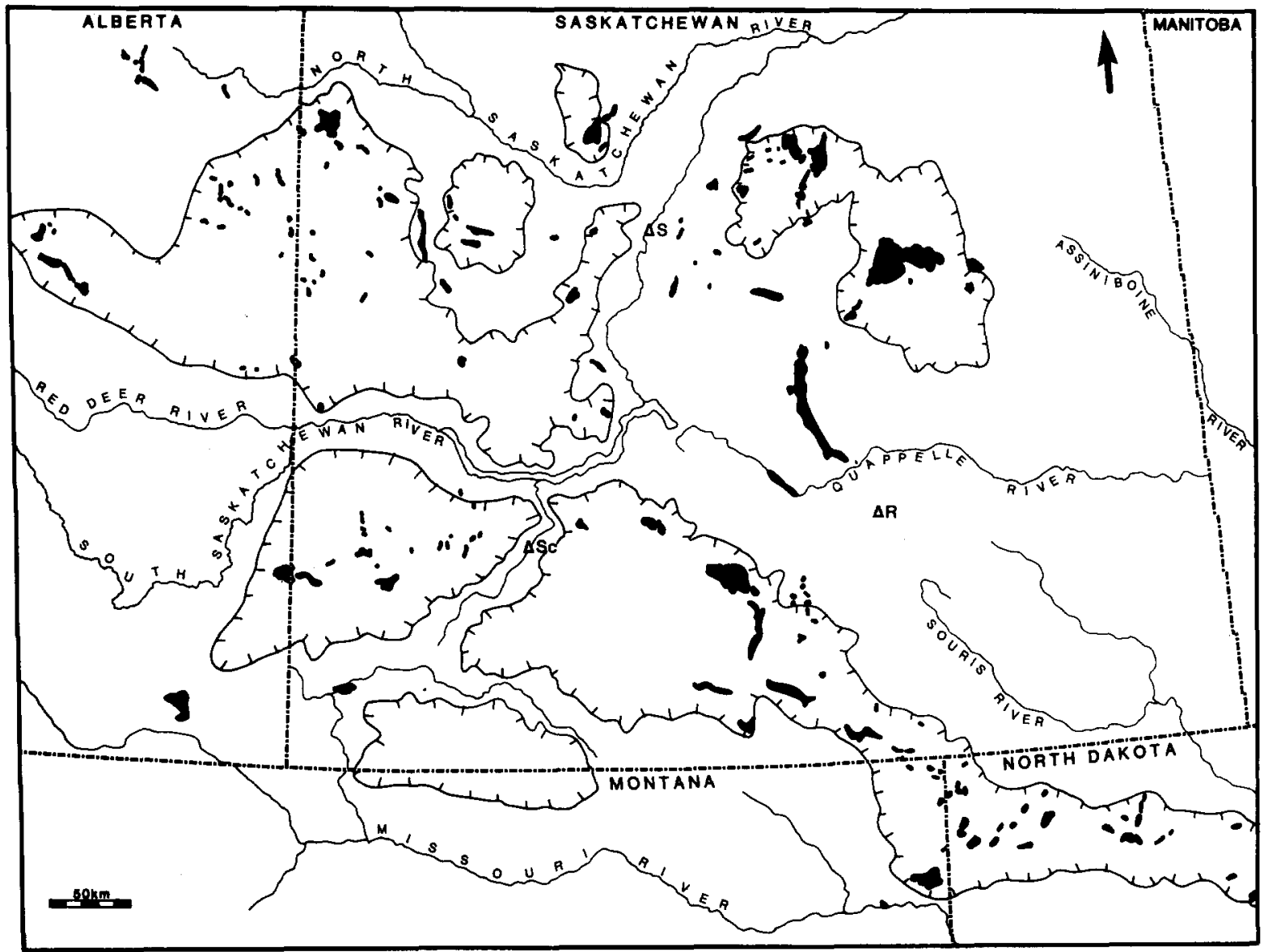

Fig. 1. Map of the Great Plains of western Canada and northern United States showing saline lakes (shaded) and areas of internal drainage (indicated by hash marks). $\mathrm{R}=$ Regina; $\mathrm{SC}=\mathrm{Swift}$ Current; $\mathrm{S}=$ Saskatoon. Compiled in part from Hammer \& Haynes (1978); Cole (1926); Tomkins (1954); and Grossman (1949, 1968).

(1944) and, more recently, the outstanding efforts of Hammer and associates (Hammer 1978a, b; Hammer \& Haynes 1978; Hammer et al. 1978; Haynes \& Hammer 1978; Lawrence 1978; Lawrence et al. 1978; Tones \& Hammer 1975). However, with a few notable exceptions (e.g., Cole 1926; Tomkins 1953, 1954; Grossman 1949, 1968; Rueffel 1968; Whiting 1974; Lieffers 1981), little attention has been given to the sedimentary realm of the lakes. This is somewhat surprising because these lakes are important sources of economic minerals, are easily accesible and, most importantly, offer a wide range and diversity of sedimentary styles.

The specific purposes of this paper are to: (1) outline the results of our reconnaissance geological work on the saline lakes of the northern Plains, and
(2) place this, and previous work on these lakes, into a sedimentary process framework.

\section{Regional setting}

\section{Physiography and hydrology}

The lakes discussed in this paper are found in the Great Plains physiographic province of North America. In general, this region is characterized by hummocky to gently rolling topography. Local relief ranges up to $70 \mathrm{~m}$ except in the vicinity of glacial spillways where deeper, often terraced valleys have been cut. The Missouri Coteau, a distinct, $50 \mathrm{~km}$ wide band of knob and kettle topography, extends 
for over $1200 \mathrm{~km}$ through this area from central South Dakota northwestward into southern Saskatchewan. Because of its lack of integrated drainage, the Coteau contains many saline lakes.

In addition to the closed basins associated with the Missouri Coteau; large areas of internal drainage with numerous salt lakes exist in the vicinity of Saskatoon, and west of Swift Current, Saskatchewan (Fig. 1). In total, over $90000 \mathrm{~km}^{2}$ or nearly $30 \%$ of southern Saskatchewan (south of $54^{\circ} \mathrm{N}$ ) is characterized by interior drainage.

The rest of the northern Great Plains is drained in two major directions by several large river systems. The Saskatchewan system, which includes the North and South Saskatchewan Rivers, originates in western Alberta and, together with the Qu'AppelleAssiniboine basin, drains southern Saskatchewan eastward and, ultimately north into Hudson Bay. Runoff in North Dakota, Montana and small portions of southern Saskatchewan and Alberta is directed south into the Missouri River system and the Gulf of Mexico.

\section{Climate}

Overall, the Great Plains experience a cold continental climate. Mean daily temperature during January in Swift Current, Saskatchewan, is about $-15^{\circ} \mathrm{C}$; during July it is $18^{\circ} \mathrm{C}$. However, significant variations do exist because of the large geographic area and local relief. One of the most important climatic factors in helping to create and maintain the saline lakes of this region is the high evaporation/precipitation ratio. Average annual precipitation over most of the region is about $30 \mathrm{~cm}$, whereas more than $125 \mathrm{~cm}$ of water can be lost through evaporation from open water bodies (CNC/IHD 1978; McKay \& Stichling 1961).

\section{Geology}

The northern Great Plains are underlain by nearly horizontal Phanerozoic sedimentary rocks of thicknesses up to $5500 \mathrm{~m}$. The lower (Paleozoic) section consists mainly of a series of stacked carbonate-evaporite cycles in contrast to the overlying (Mesozoic and Cenozoic) bedrock which is dominantly a sand-shale sequence. Dissolution of the highly soluble Paleozoic evaporites by groundwater has modified the relatively simple structural relationships of the flat-lying formations and created collapse structures over much of the area (Christiansen 1967a, 1971). Grossman (1968) suggests that this evaporite dissolution has provided a source of ions for the salt lakes of the region.

The bedrock surface has also been strongly modified by preglacial erosion. By the start of the Quaternary Period a mature, dendritic drainage pattern had been established over much of the northern Great Plains (Stalker 1961; Christiansen 1967b). Overall, this ancestral pattern is reflected by today's streams, except that much of the present-day Missouri drainage actually flowed northward to Hudson Bay rather than into the Mississippi River basin (Meneley et al. 1957).

The bedrock of the region is mantled by unconsolidated Quaternary sediment in places over $300 \mathrm{~m}$ thick. These deposits consist of till, fluvial sands and gravels, and lacustrine silts and clays (Prest 1970). Furthermore, minor folding and thrust faulting of the underlying bedrock has occurred in many areas as continental ice sheets have overridden the region (Christiansen \& Whitaker 1976).

Two aspects of the surficial sediments have had significant impact on the saline lakes: (1) During deglaciation, meltwater from the retreating glacier carved numerous ice-marginal channels and spillways. Although now abandoned or buried under more recent sediment, these depressions are often sites of saline lakes. (2) The hydrodynamic properties of the Quaternary sediments (porosity and permeability) influence, to a major degree, the location and development of the saline lakes by controlling the direction of flow and quantity of groundwater discharge.

\section{Economic significance}

Nearly all of the published geological work on saline lakes in the Great Plains has been of an economic nature. Anhydrous sodium sulfate has been commercially produced from lakes in Saskatchewan since 1918. Total composite reserves are among the largest in the world (Weisman \& Tandy 1975). At present, about 500000 tonnes of sodium sulfate is produced per year from lakes in Saskatchewan and Alberta. In 1981 the total value of this product exceeded $\$ 40,000,000$ (Fig. 2) making Canada the world's leading producer. 

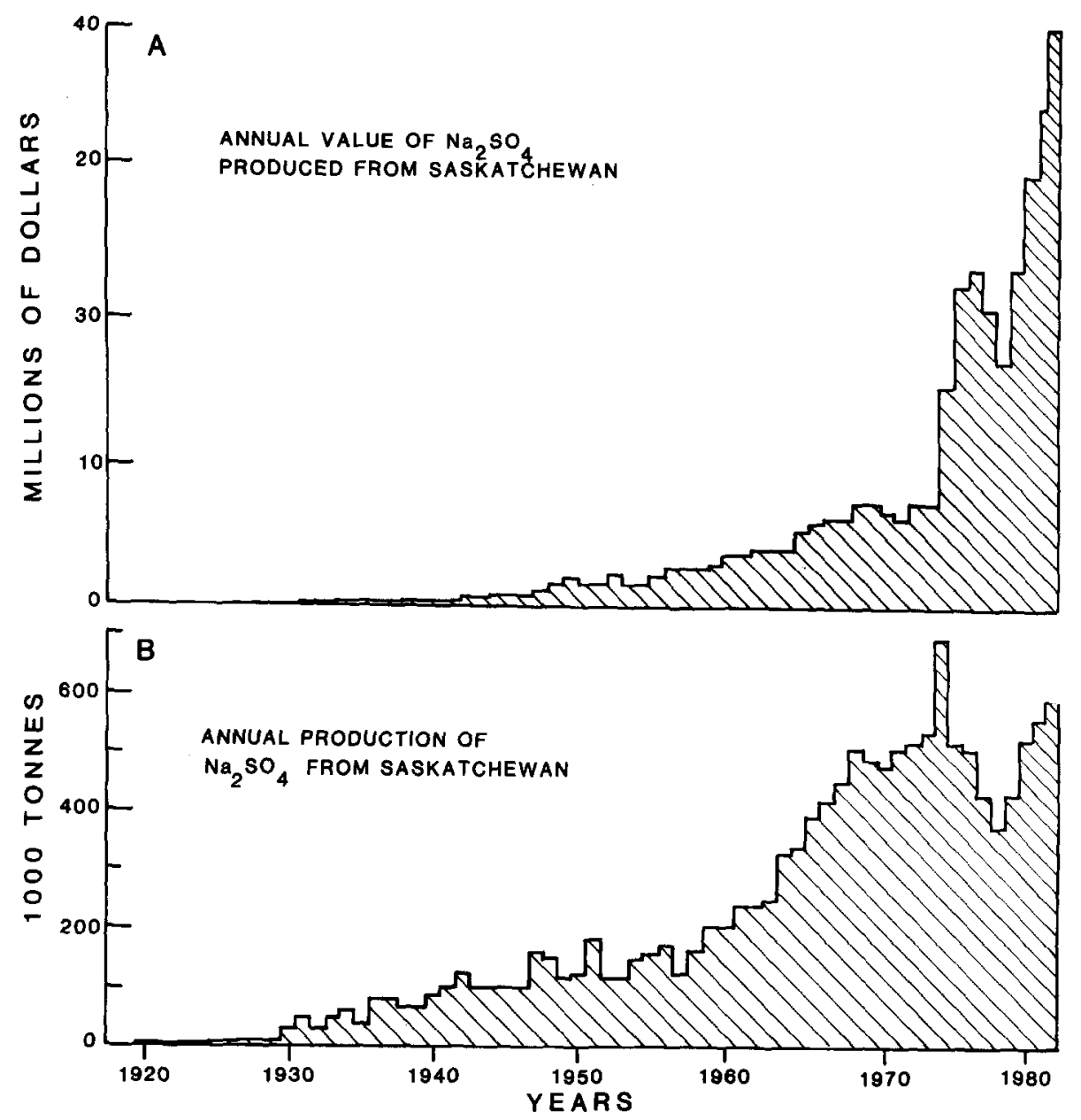

Fig. 2. Historical variation in (A) value and (B) amount of sodium sulfate produced from saline lakes in Saskatchewan (compiled from various provincial and federal government sources).

Sodium sulfate, which is used mainly in the pulp and paper industry, is presently produced by pumping saturated lake brine into artificial reservoirs and allowing mirabilite ('Glauber's salt', $\mathrm{Na}_{2} \mathrm{SO}_{4}$. $10 \mathrm{H}_{2} \mathrm{O}$ ) to precipitate upon brine cooling. By controlling the density and composition of both the lake brine and the reservoir solution, a relatively pure $\mathrm{Na}_{2} \mathrm{SO}_{4} \cdot 10 \mathrm{H}_{2} \mathrm{O}$ product can be formed and harvested. In addition, to this type of lake brine precipitation-harvesting process, the actual solid salt crystal within the lake's bed is extracted by dredge mining and solution mining.

The harvested sodium sulfate must then be dehydrated before marketing. Although a number of methods have been developed, most producers simply raise the temperature of the salt to above its fusion point (about $32^{\circ} \mathrm{C}$ ) and then either continue heating to evaporate the water of crystallization or remove the solid anhydrous precipitate from the $\mathrm{Na}_{2} \mathrm{SO}_{4}-\mathrm{H}_{2} \mathrm{O}$ slurry (Tomkins 1954; Rueffel 1968).

In addition to sodium sulfate, several saline lakes in Saskatchewan and Alberta contain a sufficient amount of magnesium to be considered marginally economic. Magnesium salts were extracted from Muskiki Lake (about $50 \mathrm{~km}$ east of Saskatoon) for a short time during the early part of the century (Cole 1926); Tomkins (1953) lists the total magnesium reserves in saline lakes of the Canadian Plains at about 5000000 tonnes. 


\section{Character and classification of the lakes}

\section{General}

By 'saline lake' we are referring to a lake that normally contains more than $3 \%$ solutes. As would be expected, considering the large number of individual basins involved and the influence of variable topography, climate and geology over this large geographic area, there is a considerable range of saline lake types and sediment characteristics in the northern Great Plains. The lakes are generally small and shallow. Thermal and, in some cases, chemical stratification occurs in the deeper basins. In a survey of 60 lakes in southern Saskatchewan, Hammer (1978b) showed that most have salinities less than that of seawater. However, data from the numerous intermittent (playa) lakes were not included in his report. The salinity is usually dominated by sulfate and either sodium or magnesium ions (Hammer 1978b; Rawson \& Moore 1944). There are few chloride, carbonate, or calcium-rich salt lakes.

For purposes of discussion, the salt lakes of the region can be grouped using a number of different geolimnological parameters. The most useful and convenient classification schemes from a sedimentological perspective are based on: (1) basin morphology, (2) water chemistry and (3) sediment type.

\section{Basin morphology}

One of the easiest ways to classify the saline lakes of the Great Plains is on the basis of basin size and shape. As pointed out by Hakanson (1977), morphology has a profound influence on the sedimentological processes and resulting spatial distribution of clastic sediment within a lake basin. The morphology of the basin also exerts considerable control on the distribution of chemical precipitates in lakes (Jones \& van Denburgh 1966; Reeves 1968).

Figure 3 shows a classification of salt lakes in the Great Plains with respect to size, depth, and degree of permanence. There are relatively few lakes in this region that can be classified as large (greater than $100 \mathrm{~km}^{2}$ ). The two largest lakes, Big Quill and Old Wives lakes, are among the six largest inland saline

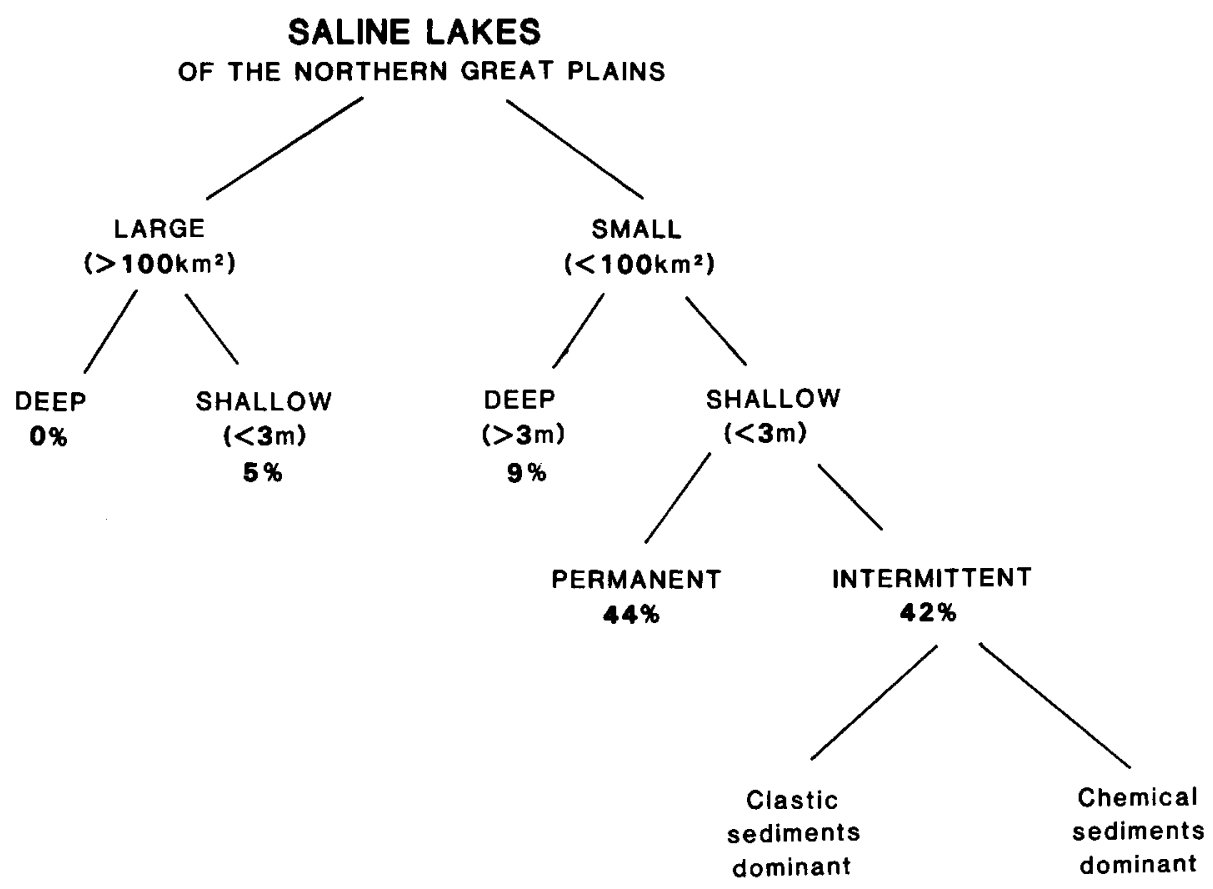

Fig. 3. Classification of saline lakes of the northern Great Plains based on size, depth and degree of permanence. Percentage calculations are based on a total of 131 saline lakes. 
lakes in North America. The sediments of these large shallow lakes are dominantly poorly-bedded, organic-rich silts and clays. In addition, Langham (1970) reports the presence of (unidentified) salt crystals in the near-surface sediment of Big Quill Lake suggesting that minor endogenic or authigenic chemical precipitation occurs.

Only about $10 \%$ of the salt lakes in the region are deep (greater than $3 \mathrm{~m}$ mean depth) and all of these are less than $100 \mathrm{~km}^{2}$. The deposits of these lakes show considerable variability in response to the chemical and thermal characteristics of each brine system. The sediments are generally fine-grained, organic-rich and well laminated. Because of the lack of post-depositional modification by bioturbation and bottom currents, the deposits of meromictic lakes (such as Waldsea and Deadmoose lakes) are good records of the history of the basin and the evolution of the lake brine.

Of the many small shallow salt lakes, one further distinction can be made based on the relative degree of permanence. About half of these remaining lakes exhibit playa* characteristics, filling with water during the spring and early summer and usually drying completely by late summer. No regular records of brine depth have been kept for any of these lakes, but maximum water depths during the past 60 years probably have not exceeded $1 \mathrm{~m}$ (Cole 1926. Tomkins 1954; Grossman 1949). Playa lake sediments are strikingly different than sediments deposited under perennial lake conditions. The playa surface is usually dominated by evaporites

* The term 'playa' as used in this report refers to the intermittently flooded low area of a basin (Reeves 1978) and does not have any more precise geomorphic or climatic implications. and surrounded by mudflats and sandflats that contain efflorescent crusts and authigenic salt beds and crystals. In contrast, the perennial salt lake deposits are mainly fine-grained clastics with minor amounts of very soluble endogenic and authigenic salts. The sediments of the perennial lakes can also contain large quantities of less soluble precipitates, particularly carbonates and sulfates.

\section{Brine chemistry}

Another useful classification scheme is based on hydrochemistry. The composition of the lake water determines which minerals can be precipitated from the brine, which sedimentary components can be re-dissolved, and how rapidly these reactions can occur.

As shown in Fig. 4, the lakes range from relatively dilute or brackish water (less than $3 \mathrm{~g} \mathrm{~kg}^{-1}$ dissolved solids) to very concentrated brines (greater than $300 \mathrm{~g} \mathrm{~kg}^{-1}$ dissolved solids). Chemically, the lakes are mainly of the $\mathrm{Na}-\mathrm{Mg}-\mathrm{SO}_{4}$ type (Hammer 1978b), although significant variations do exist both regionally as well as on a smaller, individual drainage basin scale. Figure 5 shows this regional variation in ionic composition of salt lake brines. Lakes with the highest proportion of sodium occur in the northwest and southeast sections, whereas magnesium-rich brines are most common in the southwest and northeast. High calcium lakes occur in the north-central and extreme southern portions of the region. Though nearly all of the lakes are sulfate-rich, the highest sulfate levels occur in the eastern two-thirds of the region. Lakes in the west have relatively higher chloride and bicarbonate contents. These regional differences in lake water

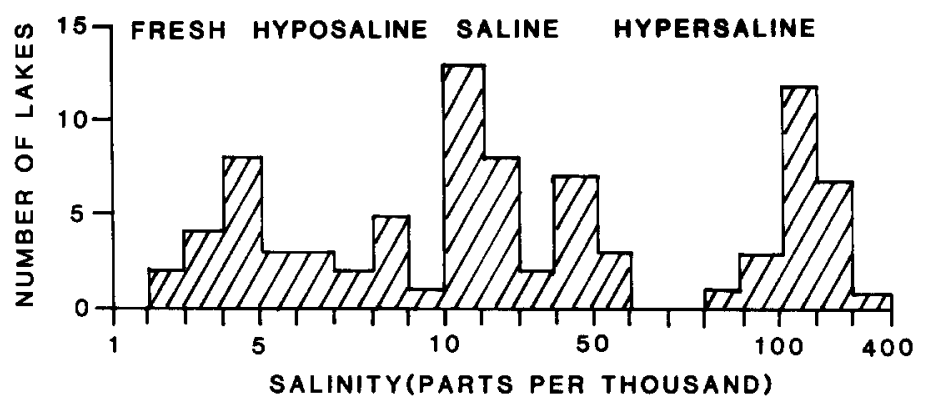

Fig. 4. Histogram showing number of lakes with salinities from 1 to 400 ppt TDS. Compiled in part from Tomkins (1953, 1954); Grossman (1949, 1968); Cole (1926); and Hammer (1978b). 

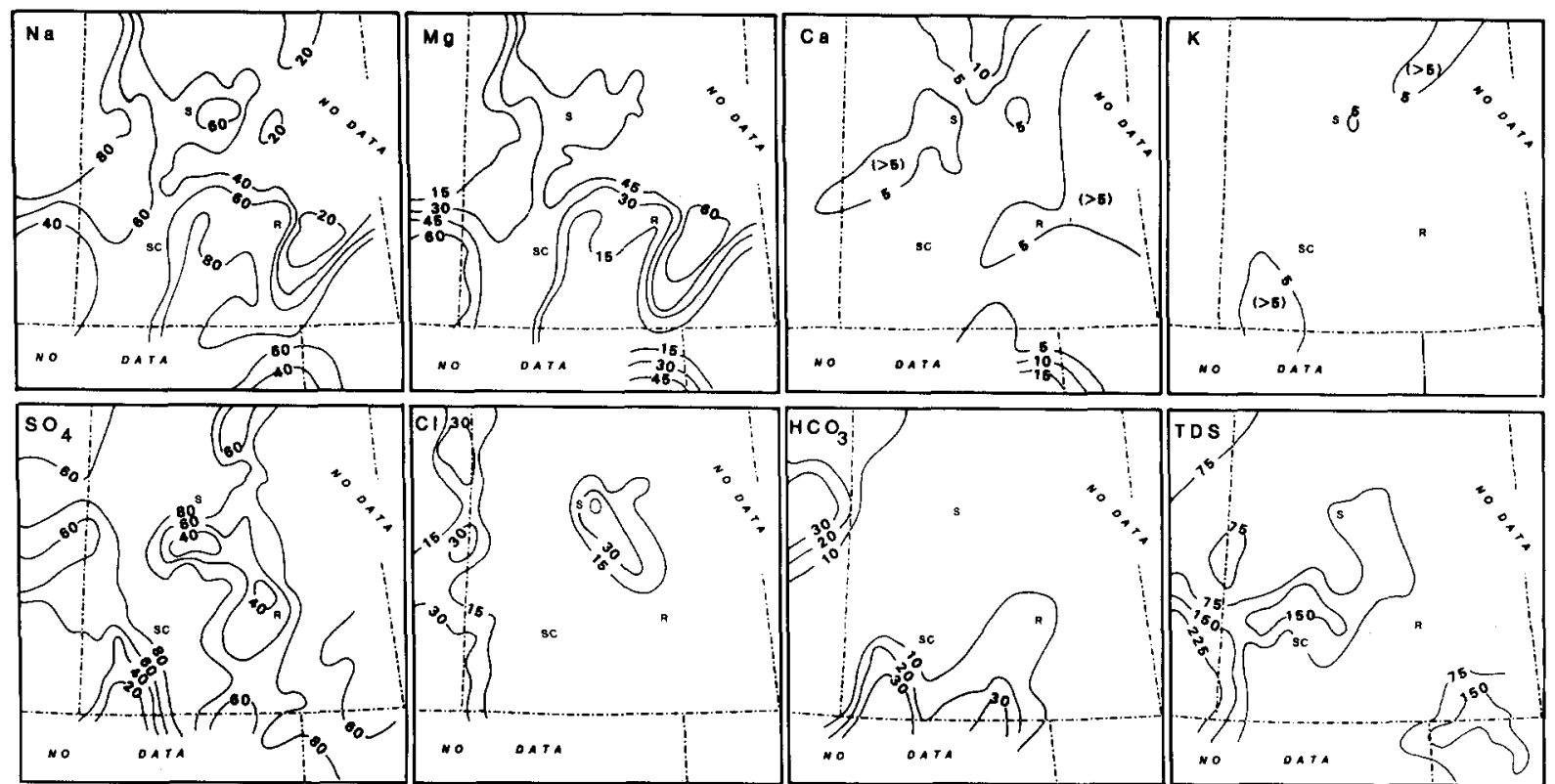

Fig. 5. Regional variation in ionic composition (percent equivalents) and total dissolved solids ( $\%$ ) of saline lakes in the northern Great Plains. Area of each map is the same as that shown in Figure 1. $R=$ Regina; $S C=S$ wift Current; $S=$ Saskatoon. Seventy-nine saline lakes were used for the contouring. Sources are as indicated in Figure 4.

chemistry probably reflect the combined influences of climatic zonation and geological variability, although the precise roles of these two factors cannot presently be evaluated.

Superposed on this regional variation are distinct local compositional trends. For example, Jones \& van Denburgh (1966) identify a sequence of decreasing bicarbonate, increasing magnesium and increasing salinity in a chain of connected salt lake basins in northern North Dakota (Fig. 6). This trend is presumably due to the sequential precipitation of calcium bicarbonate, followed by calcium sulfate, and finally sodium sulfate through the lake chain (Callender 1968; Jones \& van Denburgh 1966).

Essentially all of the saline lakes of the northern Great Plains are saturated or supersaturated with respect to calcium and magnesium carbonates (calcite, aragonite, dolomite, huntite, nesquehonite, hydromagnesite). Lakes with high salinities (high ionic strengths) are also saturated with respect to more soluble alkali salts (Fig. 7) and precipitation of minerals such as gypsum, mirabilite, thenardite, bloedite and halite occurs.

\section{Sediment type}

The character and composition of the lacustrine deposits are important factors in attempting to deduce the processes that control the brine chemistry and that are responsible for sedimentation in the saline lakes. Table 1 summarizes the surface and near-surface sediment mineralogy of the lakes. The modern lacustrine sediments are composed of: (1) very soluble evaporites, (2) sparingly soluble precipitates, (3) allochthonous or clastic inorganic material, and (4) organic detritus. By treating each of the three inorganic sediment types as endmembers, it is possible to subdivide and evaluate variability in the salt lakes with a triangular diagram (Fig. 8). Although some salt lakes may be composed of nearly pure 'end-member' components, most are mixtures of the three basic sediment types.

The sediment in lakes of group 1 consist mainly of very soluble salts. Most commonly these salts are sodium-magnesium sulfates (mirabilite, thenardite, bloedite and epsomite), although halite has also been identified. The salts are rarely pure and are usually mixed with at least small amounts of mud 
and less soluble precipitates. The lake basins are normally of the playa-salt pan type but several shallow perennial lakes also fall into this category.

The sediments in group 2 lakes are dominated by sparingly soluble precipitates. In lakes with sufficient bicarbonate ion availability, one or more carbonate minerals, such as calcite, aragonite, huntite,

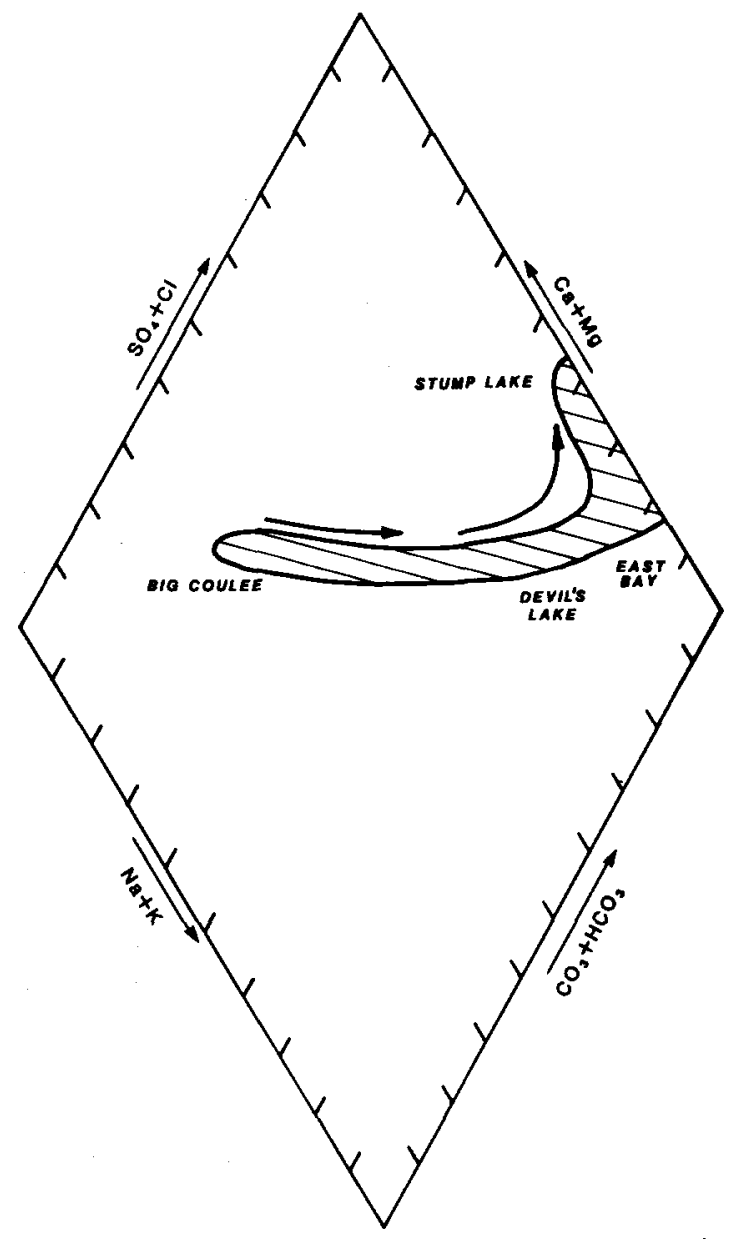

Fig. 6. Variation in major ion composition (\% epl) of water in the Devils Lake chain (from Jones \& van Denburgh 1966).

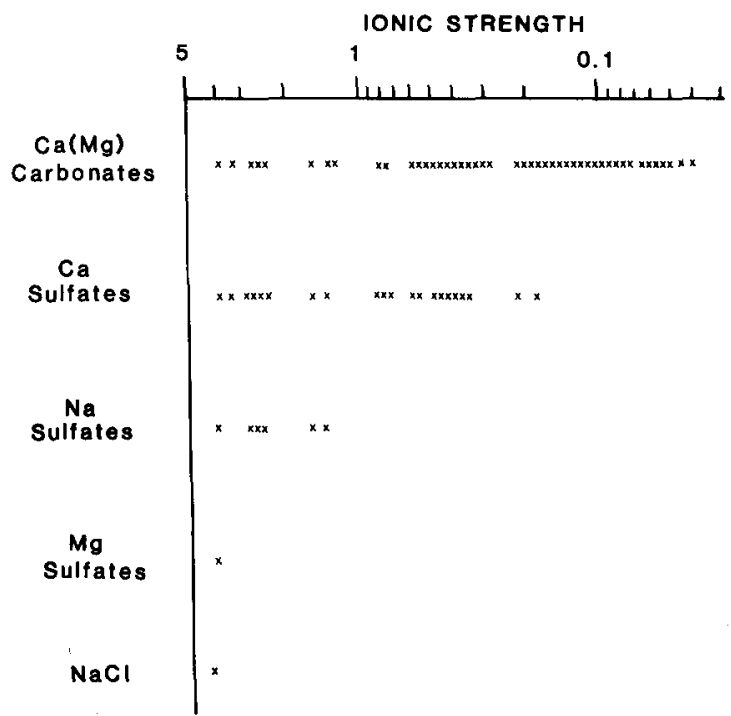

Fig. 7. Lakes showing supersaturation with respect to $\mathrm{Ca}, \mathrm{Mg}$ carbonates, $\mathrm{Ca}$ sulfates, $\mathrm{Na}$ sulfates, $\mathrm{Mg}$ sulfates, and $\mathrm{NaCl}$ versus ionic strength of the brine. Saturation calculations were done using WATSPEC (Wigley 1977). Lake water composition from Hammer (1978b), Callender (1968), Grossman (1949), Cole (1926) and unpublished data of T. Schweyen.

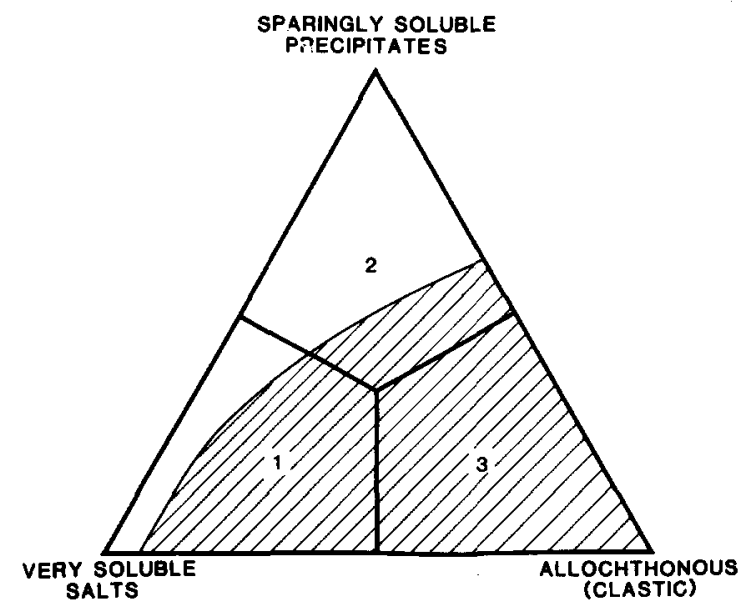

Fig. 8. Triangular diagram showing variability in lake sediment composition. Sources are indicated in Figure 4.

Table I. Minerals of the saline lakes of the northern Great Plains. (Italics indicate common occurrence; identification was done by standard $\mathrm{x}$-ray diffraction methods.)

\begin{tabular}{|c|c|c|c|c|c|}
\hline \multicolumn{2}{|l|}{ Carbonates } & \multicolumn{2}{|c|}{ Sulfates and Chlorides } & \multicolumn{2}{|l|}{ Silicates } \\
\hline Aragonite & $\mathrm{CaCO}_{3}$ & Gypsum & $\mathrm{CaSO}_{4} \cdot 2 \mathrm{H}_{2} \mathrm{O}$ & Quartz & $\mathrm{SiO}_{2}$ \\
\hline Calcite & $\mathrm{CaCO}_{3}$ & Mirabilite & $\mathrm{Na}_{2} \mathrm{SO}_{4} \cdot 10 \mathrm{H}_{2} \mathrm{O}$ & Feldspars & $\mathrm{K}-\mathrm{Na}-\mathrm{Ca}$ aluminosilicates \\
\hline High magnesian & & Thenardite & $\mathrm{Na}_{2} \mathrm{SO}_{4}$ & Kaolinite & $\mathrm{Al}_{2} \mathrm{Si}_{2} \mathrm{O}_{3}(\mathrm{OH})_{4}$ \\
\hline calcite & $\mathrm{CaCO}_{3}$ & Bloedite & $\mathrm{Na}_{2} \mathrm{Mg}\left(\mathrm{SO}_{4}\right)_{2} \cdot 4 \mathrm{H}_{2} \mathrm{O}$ & Chlorite & $(\mathrm{Fe}, \mathrm{Mg})_{2} \mathrm{Al}_{4} \mathrm{Si}_{2} \mathrm{O}_{10}(\mathrm{OH})_{4}$ \\
\hline Dolomite & $\mathrm{CaMg}\left(\mathrm{CO}_{3}\right)_{2}$ & Loeweite & $\mathrm{Na}_{12} \mathrm{Mg}_{7}\left(\mathrm{SO}_{4}\right)_{13} \cdot 15 \mathrm{H}_{2} \mathrm{O}$ & Illite & hydrous $\mathrm{K}-\mathrm{Mg}-\mathrm{Fe}$ aluminosilicate \\
\hline Nesquehonite & $\mathrm{Mg}\left(\mathrm{HCO}_{3}\right)(\mathrm{OH}) \cdot 2 \mathrm{H}_{2} \mathrm{O}$ & Kieserite & $\mathrm{MgSO}_{4} \cdot \mathrm{H}_{2} \mathrm{O}$ & Montmorillonite & hydrous $\mathrm{Mg}$ - $\mathrm{Fe}$ aluminosilicate \\
\hline Huntite & $\mathrm{CaMg}_{3}\left(\mathrm{CO}_{3}\right)_{4}$ & Epsomite & $\mathrm{MgSO}_{4} \cdot 7 \mathrm{H}_{2} \mathrm{O}$ & Mixed-layer clay & variable \\
\hline Ankerite & $\mathrm{Ca}(\mathrm{Fe}, \mathrm{Mg})\left(\mathrm{CO}_{3}\right)_{2}$ & $\begin{array}{l}\text { Halite } \\
\text { Hydrohalite }\end{array}$ & $\begin{array}{l}\mathrm{NaCl} \\
\mathrm{NaCl} \cdot 2 \mathrm{H}_{2} \mathrm{O}\end{array}$ & Muscovite & $\mathrm{K}_{2} \mathrm{Al}_{4} \mathrm{Si}_{6} \mathrm{Al}_{2} \mathrm{O}_{20}(\mathrm{OH}, \mathrm{F})_{4}$ \\
\hline
\end{tabular}


nesquehonite or dolomite (protodolomite), form either as direct precipitates or very early diagenetic products. As shown elsewhere (e.g. Müller et al. 1972; Müller \& Wagner 1978; Dean \& Gorham 1976), the specific carbonate mineralogy is determined, to a major degree, by the Mg:Ca ratio of the precipitating solution. In Waldsea Lake for example, aragonite occurs as a primary precipitate rather than calcite because of the high $\mathrm{Mg}$ :Ca ratio (14) of the brine (Fig. 9a). If removal of calcium by carbo-
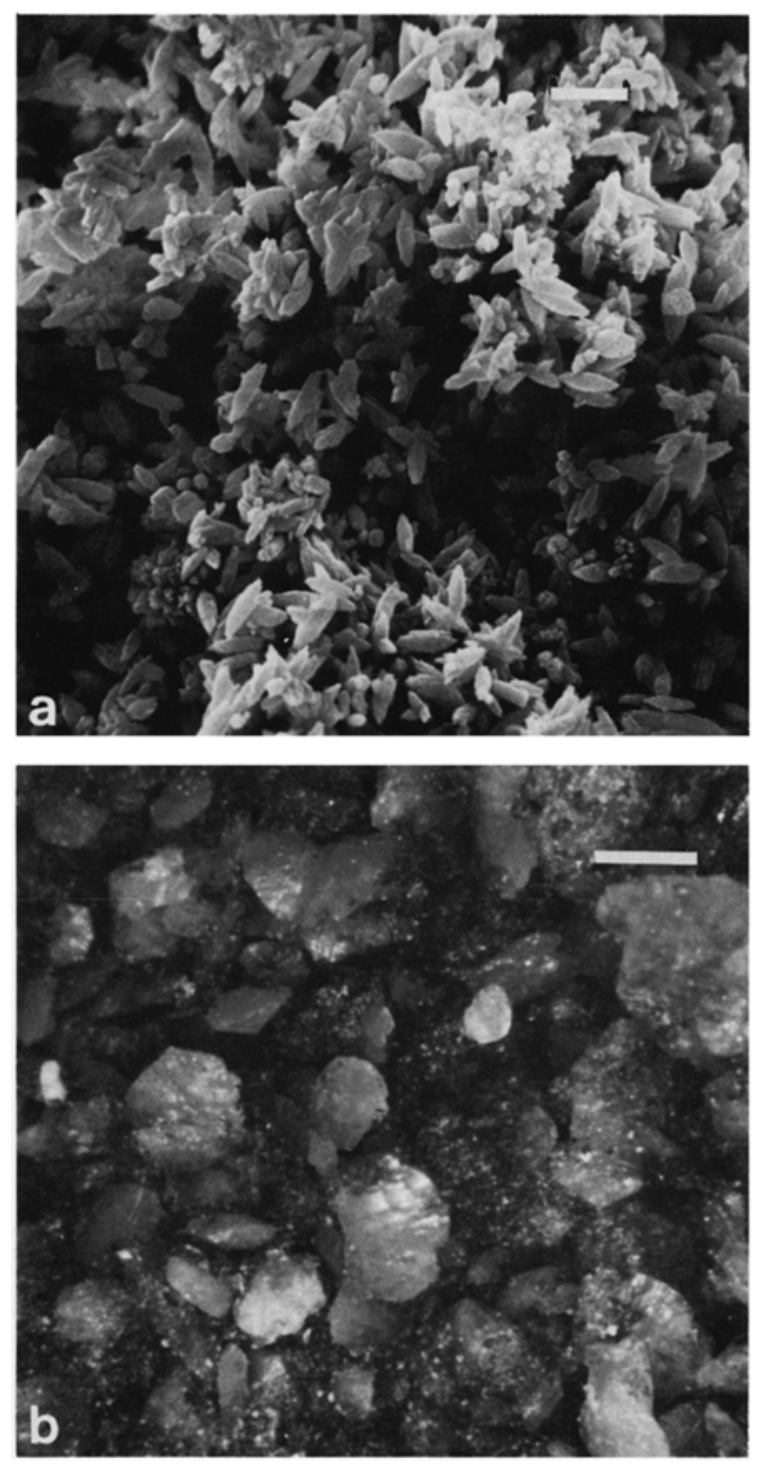

Fig. 9. (a) Scanning electron photomicrograph of aragonite from Waldsea Lake. Scale bar equals $5 \mu \mathrm{m}$. (b) Photomicrograph of gypsum from Waldsea Lake. Scale bar equals $1.5 \mathrm{~mm}$. nate precipitation is incomplete in these lakes, gypsum is also found as a 'sparingly soluble' mineral (Fig. 9b).

In addition to the precipitation of these carbonates and sulfates, clay mineral authigenesis likely occurs in lakes having elevated levels of dissolved silica and alumina. In laboratory simulations using natural brines, a mixed-layer smectite formed as a co-precipitate with nesquehonite (Fig. 10).

The sediments in lakes of group 3 are composed mainly of clastic material brought into the lake by surface runoff, shoreline erosion and wind. This sediment is dominantly silt and clay-sized quartz, feldspars, carbonates and clay minerals. Minor amounts of coarser grained components (sand, gravel) are also found in mary basins.

\section{Process sedimentology}

\section{General}

Despite the major advances in our understanding of inland saline lakes that have occurred over the past 10 years, a good case could still be made for regarding salt lakes as one of the least understood sedimentary environments. The complexity of the

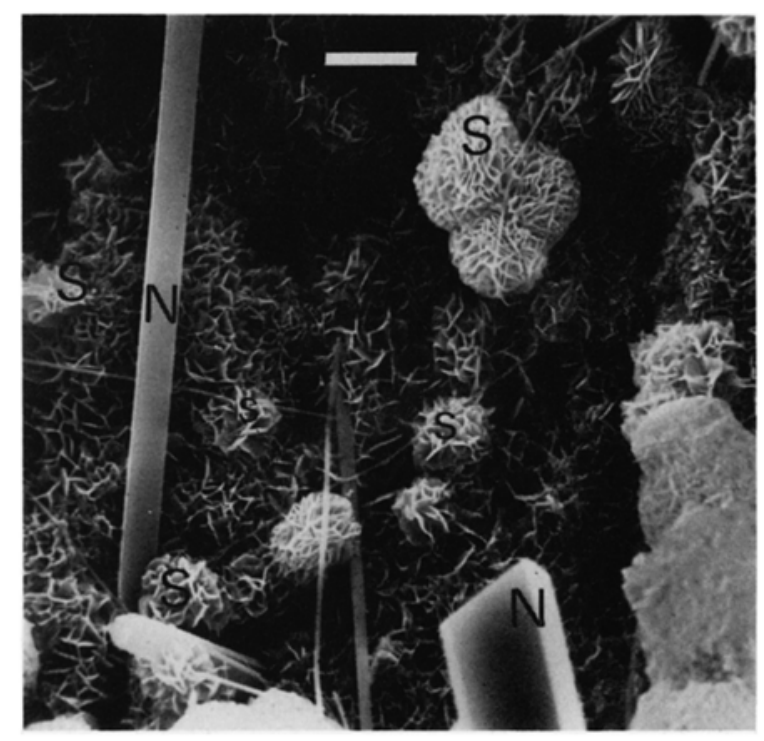

Fig. 10. Scanning electron photomicrograph of 'synthetic' precipitate showing mixed layer smectite (S) and nesquehonite $(N)$. Scale bar equals $5 \mu \mathrm{m}$. 
saline lake environment arises from a significant interplay among the various processes that: (a) form the sediment, (b) transport the sediment, and (c) destroy or modify the sediment. Add to this the dynamic nature of the lacustrine environment, particularly the rapid response to small changes in climate and hydrology, and it becomes immediately apparent that the process-response sequence in salt lakes must undergo more rigorous field and laboratory study.

In the northern Great Plains this 'sediment information gap' is particularly noticeable in light of the relatively good chemical and biological data base that already exists. Indeed, it is virtually impossible to quantitatively interpret and discuss brine chemistry and evolution without a thorough knowledge of the sedimentary and diagenetic processes operating in these basins.

Many individual physical and chemical processes that influence the formation, character and behavior of lacustrine sediments have been described and discussed in the literature (e.g., Sly 1978, 1973; Golterman 1977; Lee 1970). Eugster \& Hardie (1978) and Hardie et al. (1978) review the dominant processes influencing saline lakes in general, but give particular attention to basins occurring in arid, high-relief environments. Table 2 summarizes the non-biological processes that we feel are either the most obvious or that are of major importance in influencing the sediment record of saline lakes in the northern Great Plains region. Unfortunately, at the present time our understanding of a number of possibly significant processes is still incomplete and, therefore, this listing should be considered tentative.

Both evaporative concentration and groundwater contribution are important processes in all of the saline lakes. In addition, a number of other physical and chemical processes affect the sedimentary regime of these basins. Distinction between the processes operating in intermittent (playa) lakes and those at work in perennial salt lakes is necessary in order to emphasize the contrasting depositional styles. However, it should be stressed that many of the present-day perennial lakes of the region were probably playas during the warmer and drier Hypsithermal interval.

The development and maintenance of a saline lake in the Great Plains can be viewed most simply as a three-step process. First, a basin must be creat-
Table 2. Processes influencing sedimentation in the saline lakes of the Great Plains.

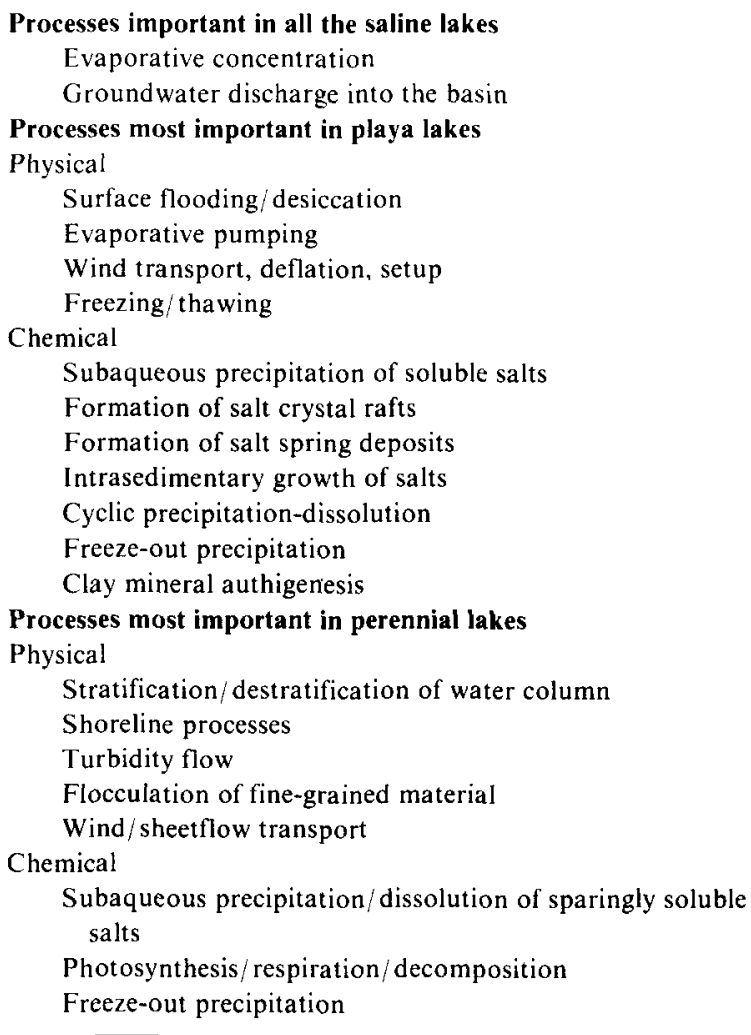

ed that is capable of ponding water. Hammer (1978b) and Tomkins (1954) maintain that all the saline lake basins in Saskatchewan were formed by glacial action or by related glacial meltwater activity. Thus, the origin of these lakes is different than that of the well-studied intermontane basins of western United States and eastern Africa or the deflation basins of the southern Great Plains and Australia.

Secondly, the lake must acquire solutes. Of the many possible sources of solutes and routes of inflow to a basin, groundwater plays a dominant role in the salt lakes of the Great Plains. Both brine and brackish water springs and seeps are common geomorphic features on the surface of the playa lakes (Fig. 11). Individual lake bottom springs having measured discharges of up to $7 \mathrm{~m}^{3}$ minute ${ }^{-1}$ (Cole 1926) and salinities in excess of $200 \mathrm{~g} \mathrm{~kg}^{-1}$ (Grossman 1949) confirms the importance of groundwater contribution to these salt pans. In perennial lakes, the presence of tufas and carbonate 


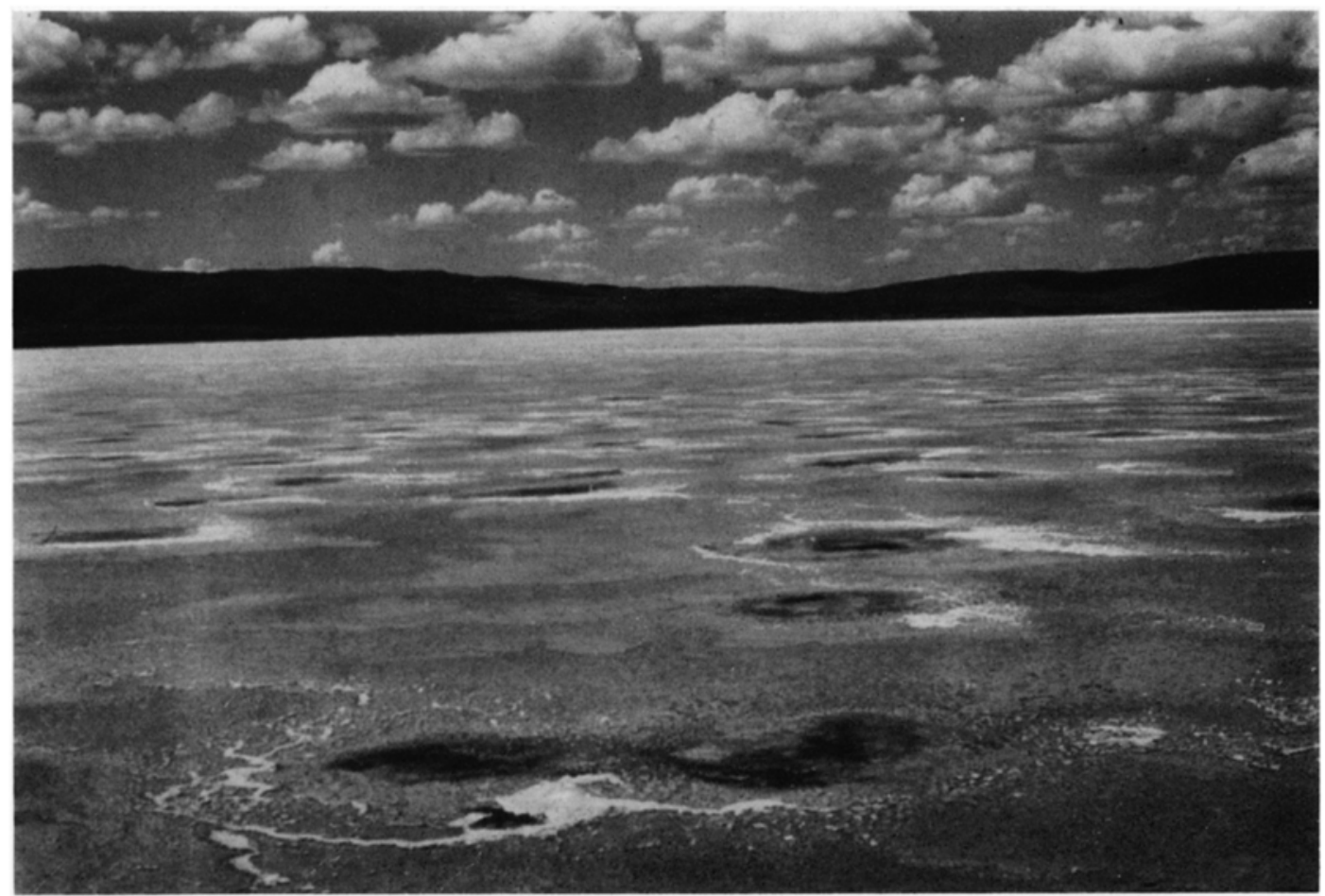

Fig. 11. Boot Lake, Saskatchewan, showing numerous lake-bottom springs.

hardgrounds in the offshore sediments is further indication of subaqueous spring discharge.

Finally, the solutes must be concentrated by evaporation. Water loss of over $100 \mathrm{~cm}$ per year through intense evaporation results in the buildup of dissolved components in the lakes. In small, shallow basins the rate of evaporation is closely associated with the rate at which solar and wind energy are supplied to the water surface. In the deeper basins, energy storage in the form of heat becomes an important factor and high evaporation rates may actually occur during autumn when the temperature of the brine is considerably higher than that of the air (CNC/IHD 1978).

\section{Physical and chemical processes of playa lakes}

In addition to ground water contribution, the intermittent lakes seasonally receive water from direct precipitation, diffuse overland runoff and small streams. This seasonal basin flooding affects the sediment in several ways. Most importantly, the dilute brine occupying the basin during wet periods is capable of redissolving previously precipitated soluble salts. The amount of dissolution is controlled by the nature of the inflowing water (temperature, suspended load, salinity, composition, etc.) and the kinetics of dissolution of the precipitated phases. A partial or total re-solution of the previous year's precipitate or even of older salt beds can occur. For example, in Lydden Lake, a $10 \mathrm{~km}^{2}$ salt pan about $100 \mathrm{~km}$ west of Saskatoon, complete dissolution of the salt crust and partial dissolution of the underlying 'permanent' salt bed during the spring of 1981 created an irregular, hummocky surface of the playa floor with solution depressions up to $20 \mathrm{~cm}$ deep. By September these irregularities were refilled with newly precipitated salt.

The seasonal influx of water also transports clastic sediment to the basin and allows this material to be distributed and sorted within the lake. Unfortunately, without specific study it is impossible to estimate the amount of sediment transported to a given playa by sheet-flow as compared with stream 
flow. Once in the, lacustrine environment, the coarser fraction of the sediment is often reworked into small beaches and bars by normal shoreline processes, whereas the finer components are transported basinward and eventually deposited as thin mud laminae on the playa floor. It is likely that this deposition is aided by flocculation of clay-sized material upon exposure to the saline waters.

Evaporation of the ponded water during summer lowers the level of the brine, thereby subaerially exposing the margins of the basin and creating a mudflat perimeter. The newly-exposed mudflats often become encrusted with white, finely crystalline salts that are formed by the evaporation of brine films brought to the surface by capillary action and evaporative pumping. These efflorescent crusts, which can be up to $12 \mathrm{~cm}$ thick, have a distinctive bulbous appearance (Fig. 12) and are usually monomineralic. The crusts are dry and porous, and are easily eroded by ablation or dissolved by runoff from a summer shower.

Two types of mudflats have been recognized in these playa environments: (1) saline mudflats and (2) clastic mudflats. The saline mudflat consists of fine-grained clastic sediment with crystals of salt minerals. These salts have nucleated within the brine-saturated sediment after evaporation of the overlying lake water and occur as displacive and/or poikilitic crystal growths. The clastic mudflat is also dominated by fine-grained detrital material, but, in contrast, has no intrasedimentary salt crys-

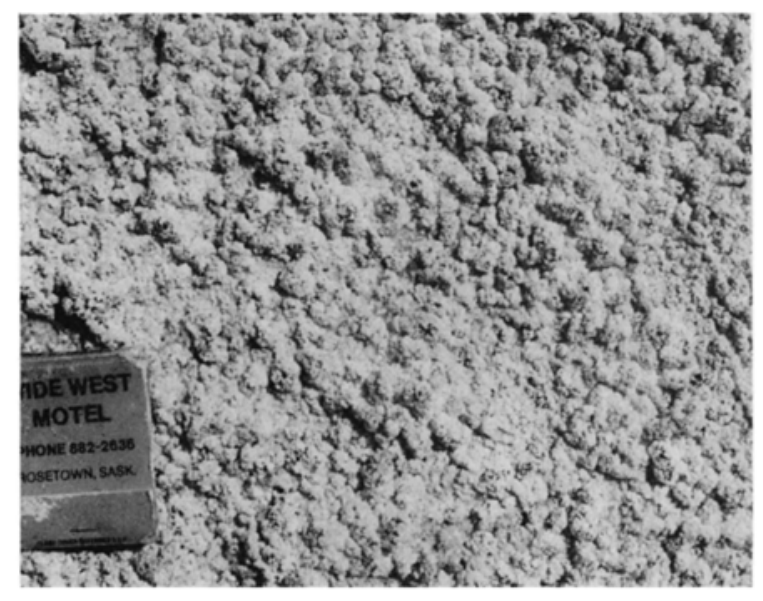

Fig. 12. Efflorescent crust on the saline mudflat at Corral Lake, Saskatchewan. Crust is entirely thenardite. Matchbook is $3.5 \mathrm{~cm}$ wide. tals and usually only a very thin efflorescent crust. Desiccation cracks are common on the surface. These clastic mudflats are zones of shallow groundwater discharge; they remain water saturated and soft throughout the season, unlike the 'dry mudflats' described by Hardie et al. (1978). Because this shallow groundwater seepage is relatively fresh compared to the lake brine, authigenic salt crystals and thick efflorescent crusts will not form.

Continued evaporation concentrates the remaining lake brine which occupies the lower portions of the playa surface. As supersaturation is reached, nucleation and growth of crystals occurs at the brine surface. Under calm conditions these crystals can be temporarily supported by surface tension (Fig. 13a) and sometimes coalesce into floating rafts (Fig. 13b). Wind may then drive large frag-
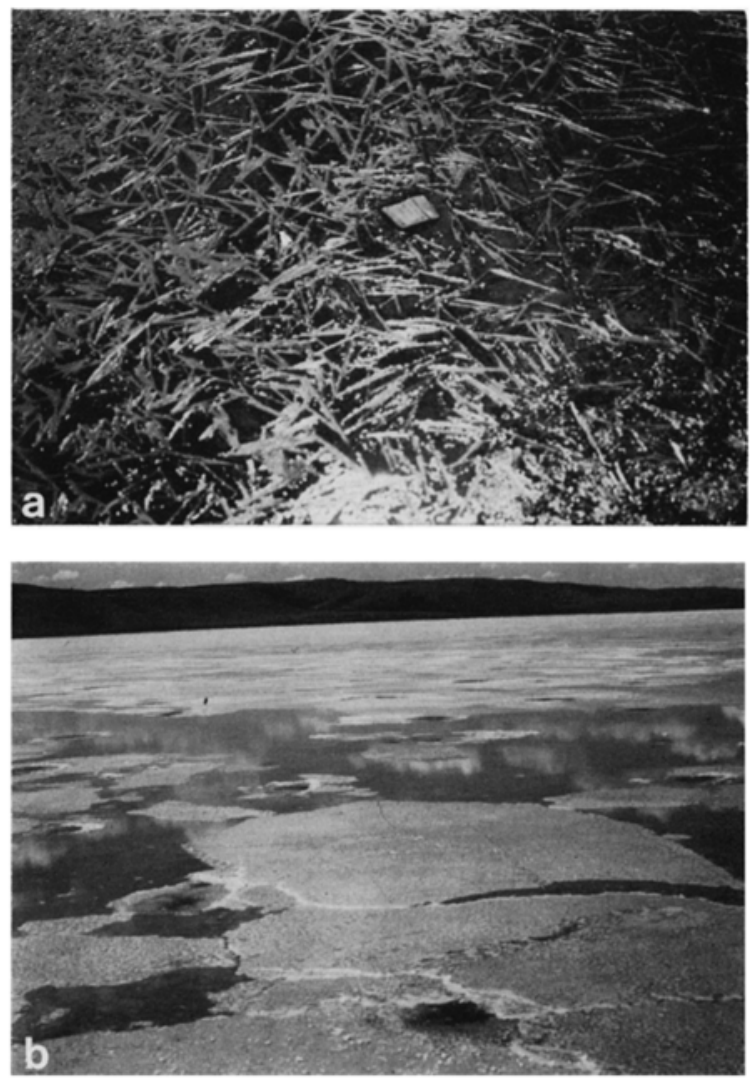

Fig. 13. (a) Delicate salt crystals formed at the surface of the brine in Ceylon Lake. Crystals are being supported by surface tension. Matchbook is $3.5 \mathrm{~cm}$ wide. (b) Coalesced crystal rafts being driven by wind across the brine surface at Ceylon Lake, Saskatchewan. 
ments of the rafts across the brine surface eventually grounding the salt on the shore or on irregularities within the lake itself.

Wind also influences distribution of the brine in these shallow lakes. Several hours of moderately strong wind from one direction can displace the entire water body toward the downwind end of the basin. Teller et al. (1982) describe similar wind 'setup' on a saline playa in Australia. Although not yet fully evaluated, the importance of this process in the lakes of the Great Plains appears to be at least twofold: (1) Wind-controlled placement of the brine can result in differences in thickness of salt from one end of a basin to the other. (2) If setup occurs in the latter stages of brine concentration, it is possible that the mineralogy of the evaporite deposits will be different from one end of the basin to the other, resulting in less soluble salts occurring in the upwind direction and the more soluble precipitates concentrated in the downwind areas.

As the brine approaches saturation with respect to sodium sulfate, temperature variation assumes a significant role in controlling salt precipitation and water chemistry. Between 10 and $30^{\circ} \mathrm{C}$, the solubility of mirabilite increases rapidly with increasing temperature (Fig. 14). Thus, a shallow brine concentrated sufficiently to be near saturation during a warm summer day will likely completely crystallize overnight as the temperature drops. The presence of a common ion salt (such as sodium chloride or magnesium sulfate) in the brine further lowers the mirabilite solubility. An extended period of repeated diurnal alteration from brine to crystal may

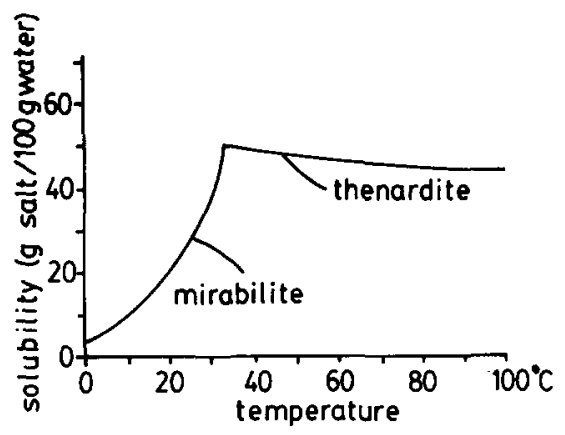

Fig. 14. Temperature - solubility curves for mirabilite $\left(\mathrm{Na}_{2} \mathrm{SO}_{4}\right.$. $\left.10 \mathrm{H}_{2} \mathrm{O}\right)$ and thenardite $\left(\mathrm{Na}_{2} \mathrm{SO}_{4}\right)$ in pure $\mathrm{Na}-\mathrm{SO}_{4}-\mathrm{H}_{2} \mathrm{O}$ solution. Transition temperature from mirabilite to thenardite is $32^{\circ} \mathrm{C}$. (After Tomkins 1954.) ensue depending on the rate of evaporation versus groundwater and surface water recharge. For example, Vincent Lake, located northwest of Swift Current, fluctuated from a 'dry' lake at night to a lake with up to $10 \mathrm{~cm}$ of water during the day throughout most of the summer of 1981 .

The salt bed deposited by complete evaporation of the ponded water is variable in thickness but averages between 10 and $20 \mathrm{~cm}$ in most of the playas of the region. Cole (1926 reports 'intermittent' crystal (= annual salt bed) thicknesses of up to $60 \mathrm{~cm}$. The salt beds are often crudely laminated. When viewed in cross-section, this layering is enhanced by differences in crystal morphology, mineralogy and, in some cases, the presence of thin discontinuous mud interbeds.

The salts are composed mainly of mirabilite except near the crust's surface where thenardite and bloedite predominate. Figure 15 shows a typical vertical section through the upper portion of the salt pan sediment. Although details of the processes operating during the final stages of brine crystallization are still being investigated, several comments can be made based on preliminary field and laboratory observation. Simple removal of water by evaporation causes precipitation of a mirabilite crust consisting of either (a) large, thin interlocking hopper crystals or (b) fine, radiating, acicular crystals depending on nucleus availability. The formation of this crust slows the rate of evaporation by isolating the underlying brine. Further slow precipitation within the saturated brine results in the formation of mirabilite in two modes: as large, pointed 'dogtooth' crystals attached to the lower surface of the crust and as interlocking clusters of equant crystals growing at the base of the brine. This precipitation enriches the remaining brine in magnesium through the preferential extraction of sodium. Dehydration of the exposed surface of the crust converts the hydrous sodium sulfate to thenardite. Leaking of the brine from beneath inundates the surface of the crust with $\mathrm{Mg}$-rich water, which then evaporates to precipitate a lamina of bloedite. Temporary reflooding of the salt pan by summer rainfall or modification by wind can complicate this near-surface stratigraphy.

If the evaporation/inflow ratio is sufficiently high, nucleation and displacive growth of crystals can occur within the mud underlying the crust. Handford (1982) discusses similar intrasedimen- 


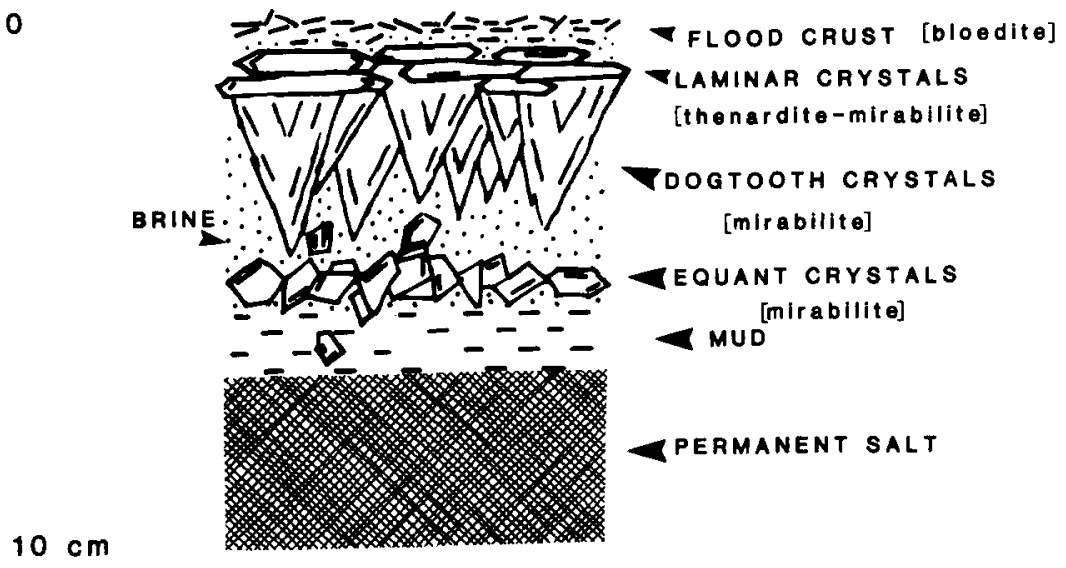

Fig. 15. Schematic profile of typical playa lake salt crust in the northern Great Plains.

tary precipitation in Bristol Lake, California, and outlines the complexity of the precipitation-dissolution events as the level of the brine fluctuates through the season.

Finally, a process unique to salt lakes in cold climates is freeze-out precipitation of very soluble minerals. If summer evaporation of the brine is incomplete, mirabilite will precipitate when the brine cools during autumn and winter. The formation of an ice cover on the brine further concentrates the remaining $\mathrm{Mg}$-rich solution resulting in precipitation of epsomite. Cole (1926) reported up to $30 \mathrm{~cm}$ of magnesium sulfate crystal (plus ice) overlying about $15 \mathrm{~cm}$ of mirabilite/thenardite in Muskiki Lake during winter. The effect of subfreezing temperatures on the diagenesis of salts already precipitated in these lakes has not yet been investigated.

\section{Physical and chemical processes of perennial lakes}

As indicated earlier, the most significant processes affecting all saline lakes of the northern Great Plains are intense evaporation and groundwater contributions to the basins. To keep the basin constantly supplied with water, perennial lakes require a lower evaporation/inflow ratio. Because deposits of perennial lakes are not regularly influenced by the processes associated with subaerial exposure, the resulting sedimentary facies are quite different than those of intermittent salt lakes. In perennial lakes significant brine lowering does not usually occur and wide peripheral mudflats with associated efflorescent crusts and secondary salt crystals are not present. Rather, sedimentation is dominated by 'normal' lacustrine processes, such as beach/shoreline erosion and deposition, delta construction, density flow and pelagic fallout sedimentation, and by subaqueous precipitation of salts. Unfortunately, our information is still sparse concerning the details of these processes in the Great Plains lakes and it is strongly biased toward the deeper, meromictic lakes and those that exhibit significant chemical sedimentation.

The supply of clastic sediment to the perennial lakes is mainly from stream flow. Wind and sheetflow can be locally important, particularly in lakes that are surrounded by agricultural land. Clastic sedimentation within the basin is controlled by several processes. First, in the marginal areas of the lakes where wind generated waves can influence the bottom, sedimentation occurs in equilibrium with the wave energy available. Coarse-grained clastics (gravel, sand) generally remain in the near-shore region, whereas the finer particles (silt, clay) are held in suspension and carried basinward. This ideal sediment distribution is complicated in many of the shallow basins because virtually the entire lake floor can be affected by wave agitation. Further modification of this general distal fining pattern is caused by accelerated settling of the fines owing to flocculation of clays in the saline water.

The importance of density flow as a depositional process in lakes has been recognized for a long time 
(Gilbert 1885; Forel 1885; Bell 1942). In addition to high density turbidity currents (underflows) that can quickly deposit relatively thick $(0.5-1.5 \mathrm{~m})$ sequences of graded sediment, lower density plumes generated from stream inflow or slump-mobilized shoreline deposits can periodically spread out across the lake basin. As described by Sturm \& Matter (1978), the level of the flow is controlled by the density difference between the flow and the lake water. Thermoclines and chemoclines can act as 'sediment traps' for large amounts of suspended matter injected into the lake by medium density interflows. A continuous fallout of the fine-grained detritus supplied by these interflows results in massive to faintly graded laminae that are indistinguishable from normal pelagic sedimentation. The occurrence of distinct turbidites in the saline lakes of the Great Plains has not yet been confirmed. Although the offshore sediment of several perennial lakes, including Waldsea, Deadmoose, Lenore and Little Manitou, contain graded intervals and relatively coarse clastic material, this evidence is not unequivocal.
Seasonal temperature variations of the perennial saline lakes have a decisive influence on the chemical precipitates within the basin. Subaqueous precipitation of mirabilite during winter months and subsequent dissolution during summer in Little Manitou Lake has been described by Rawson \& Moore (1944). Hammer (1978b) also points out that the formation of a winter ice cover can significantly increase ion concentration in the lakes and may lead to supersaturation. Table 3 lists the perennial salt lakes affected by this type of seasonal mirabilite precipitation-dissolution process and the calculated saturation indices.

One of the most important features influencing chemical sedimentation in the lakes is stratification of the water column. According to Hammer \& Haynes (1978) about a dozen saline lakes in Saskatchewan stratify thermally; two are chemically stratified. Precipitation of sparingly soluble carbonate and sulfate minerals in these lakes and their accumulation within the sedimentary record is a complex process which is not yet fully understood. Several competing factors are involved in deter-

Table 3. Calculated saturation indices of selected perennial saline lakes of the Great Plains. Positive values indicate supersaturation; negative values indicate undersaturation. Italics indicate that the lake was once dry according to Hammer \& Haynes (1978). Calculations were done using WATSPEC program (Wigley 1977). IAP = ion activity product; $\mathbf{K}_{\mathrm{sp}}=$ solubility product.

\begin{tabular}{|c|c|c|c|c|c|c|}
\hline \multirow[b]{3}{*}{ Lake } & \multicolumn{6}{|c|}{ Saturation index $\log \left(\frac{\text { IAP }}{K_{\mathrm{sD}}}\right)$} \\
\hline & \multicolumn{2}{|l|}{ Mirabilite } & \multicolumn{2}{|l|}{ Gypsum } & \multicolumn{2}{|l|}{ Calcite } \\
\hline & Summer & Winter & Summer & Winter & Summer & Winter \\
\hline Aroma & -0.93 & 0.71 & -0.07 & 0.53 & 1.21 & 1.69 \\
\hline Bitter & -0.81 & 0.19 & 0.32 & 0.42 & 0.81 & 0.65 \\
\hline Blaine South & -2.08 & 0.09 & -0.24 & 0.20 & 1.53 & 1.61 \\
\hline Chaplin East & -0.15 & 0.98 & 0.14 & 0.35 & 2.07 & 2.19 \\
\hline Chaplin West & 0.43 & 1.27 & 0.90 & 1.01 & 2.58 & 2.61 \\
\hline Landis & -1.39 & 0.13 & 0.12 & 0.60 & 1.68 & 2.04 \\
\hline Little Manitou & -1.10 & 0.32 & 0.17 & 0.27 & 1.59 & 1.58 \\
\hline Lostwood & -1.01 & 0.06 & -0.42 & -0.01 & 1.09 & 1.36 \\
\hline Louis & -2.17 & 0.01 & -0.30 & 0.14 & 1.81 & 2.08 \\
\hline Manito & -1.45 & 0.01 & -1.05 & -0.57 & 1.78 & 2.15 \\
\hline Marie & -1.88 & 0.03 & 0.19 & 0.67 & 0.87 & 1.17 \\
\hline Patience & -0.53 & 0.75 & 0.42 & 1.09 & 1.64 & 1.69 \\
\hline Porter & -1.97 & 0.48 & 0.15 & 2.08 & 1.71 & 3.47 \\
\hline Big Quill & -1.32 & 0.11 & 0.11 & 1.01 & 1.51 & 1.63 \\
\hline West Coteau & -0.84 & 0.58 & -0.11 & 0.38 & 1.46 & 1.77 \\
\hline Westby & -0.31 & 0.94 & 0.40 & 1.02 & 1.65 & 1.82 \\
\hline White & -0.54 & 0.82 & 0.06 & 0.14 & 0.62 & 0.84 \\
\hline Whiteshore & 0.37 & 1.42 & 1.26 & 1.39 & 2.17 & 2.24 \\
\hline Willowbunch & -1.22 & 0.25 & -0.65 & -0.21 & 1.97 & 2.35 \\
\hline
\end{tabular}


Table 4. Calculated saturation indices of Waldsea Lake water. Positive values indicate supersaturation; negative values indicate undersaturation. Calculations were done using WATSPEC program (Wigley 1977). IAP = ion activity product; $\mathrm{K}_{\mathrm{sp}}=$ solubility product.

\begin{tabular}{|c|c|c|c|c|c|c|c|c|}
\hline & \multicolumn{4}{|c|}{ Saturation index $\log \left(\frac{\text { IAP }}{K}\right)$} & \multirow{2}{*}{\multicolumn{2}{|c|}{ Gypsum }} & \multirow{2}{*}{\multicolumn{2}{|c|}{ Mirabilite }} \\
\hline & \multicolumn{2}{|l|}{ Calcite } & \multicolumn{2}{|l|}{ Aragonite } & & & & \\
\hline & Summer & Winter & Summer & Winter & Summer & Winter & Summer & Winter \\
\hline Surface water & 2.85 & 2.45 & 2.35 & 1.69 & 0.08 & 0.50 & -2.15 & -0.79 \\
\hline Mixolimnion & 2.12 & 1.97 & 1.95 & 1.48 & -0.99 & -0.56 & -1.75 & -1.61 \\
\hline Chemocline & 2.00 & 1.70 & 1.49 & 1.41 & 0.49 & 0.61 & -1.69 & -1.50 \\
\hline Monimolimnion & 1.35 & 1.35 & 0.89 & 0.89 & 0.60 & 0.60 & -0.92 & -0.92 \\
\hline Hypothetical overturn & 1.92 & - & 1.60 & - & -0.55 & - & -1.55 & - \\
\hline
\end{tabular}

mining whether precipitation will occur and whether the minerals will be preserved. Dean (1981), Kelts \& Hsü (1978) and Wetzel (1975) discuss the relevant chemical equilibria and annual cycle of carbonate precipitation in typical north temperate, dimictic lakes. An abundance of data confirms that the most important factor controlling precipitation of calcium carbonate in these lakes is an increase in $\mathrm{pH}$ caused by photosynthetic removal of carbon dioxide in the epilimnion. If the basinal sediments are below wave base and benthic activity is low, the seasonal cyclicity of carbonate production can result in rhythmic lamination or varves. However, more acidic conditions in the undersaturated hypolimnion/monimolimnion can dissolve a portion of the carbonate as shown by Murphy \& Wilkinson (1980).

The origin of much of the laminar aragonite and calcite in the sediments of Little Manitou, Deadmoose and Waldsea lakes is probably similar to that described above, although we have not yet verified the period of the rhythmites. The presence of thin, dark laminae within the carbonate bands indicates a greater degree of complexity than a simple annual cycle.

The calculated level of saturation with respect to several carbonate and sulfate minerals and their seasonal variation in Waldsea Lake are listed in Table 4. The entire mixolimnion of the lake is strongly supersaturated with respect to carbonates throughout the year. This saturation level decreases substantially in the chemocline and monimolimnion but the brine still remains supersaturated. Sediment trap data are presently being collected to determine whether carbonate precipitation or dissolution occurs in the lower water mass.

Waldsea Lake also shows supersaturated conditions with respect to gypsum (Table 4). During the summer supersaturation is reached in the near surface water while the remaining mixolimnion is undersaturated. Low temperatures, increased salinities and possibly the release of calcium by dissolution of carbonates that are settling through the water column also create supersaturation in the chemocline and monimolimnion. It is interesting to note that if chemical stratification were destroyed and the water completely mixed, Waldsea Lake would be undersaturated with respect to gypsum.

Gypsum in Waldsea Lake sediments occurs in several different forms and textures (Table 5). Although each crystal habit likely reflects a particular suite of physical, chemical and biological processes, definitive correlation of the environmental properties with specific habits is still incomplete. It is likely that gypsum laminae composed entirely of prismatic and lenticular crystals or mixed with carbo-

Table 5. Gypsum in Waldsea Lake sediment.

\footnotetext{
Bedded gypsum

Pure or mixed with carbonates, quartz

Beds: $0.5-4 \mathrm{~mm}$ thick

Composed of:

(a) platy and lensoid crystals, $0.005-1 \mathrm{~mm}$

(b) equant crystals, $0.01-0.06 \mathrm{~mm}$

(c) rounded grains, $0.05-0.5 \mathrm{~mm}$

Intrasedimentary

Macroscopic; isolated euhedral crystals up to $0.5 \mathrm{~mm}$ Microscopic
} 
nates are the result of primary precipitation either within the water column or at the sediment-water interface. In contrast, isolated, intrasedimentary gypsum crystals and possibly laminae composed of lensoid crystals are very early diagenetic products, precipitated in the interstitial water of preexisting sediment. The presence of rounded and pitted crystals and grains suggests abrasion by reworking or, more likely, partial dissolution.

\section{Summary and further research needs}

The sedimentology of saline lakes in the Great Plains of western Canada and northern United States is poorly understood. Despite their abundance and their importance as a source of economic minerals, relatively little modern work has been done detailing the genesis and diagenesis of these lacustrine deposits.

The lakes are generally small and shallow, of a non-tectonic origin, and dominated by sodium, magnesium and sulfate ions. The sediments are composed of variable proportions of very soluble and sparingly soluble precipitates, allochthonous material, and organic debris. The shallowest basins exhibit playa characteristics whereas the deeper basins contain perennial lakes. In terms of process sedimentology, a distinction must be made between these two basic lake types.

The most important processes affecting the sediments of the playa lakes include: cyclic flooding (salt dissolution) - desiccation (salt precipitation); formation of efflorescent crusts and intrasedimentary salts by evaporative pumping; and periodic detrital sedimentation by sheetflow, stream flow and wind. These processes combine to create a dynamic setting that fluctuates on a diurnal as well as seasonal basis.

The development of a stratified water column is an important process influencing sedimentation in many of the perennial salt lakes. This vertical inhomogeneity within the lake complicates the simple 'one-box' model of a basin with which sedimentologists are fond of working. The presence of two or more distinct layers of water, each with different flux parameters, chemistries, ion residence times and reaction mechanisms, requires special care in order to identify the important processes controlling sedimentation. Precipitation of sparingly solu- ble carbonate minerals occurs mainly in response to supersaturated conditions brought about by biological activity. Precipitation of gypsum takes place with lowered temperatures and increased brine concentration. Deposition of detrital sediment is controlled by normal lacustrine shoreline processes, turbidity underflows and interflows, and flocculation of fine-grained clays.

A major tenet of stratigraphic geology is that modern processes and resulting Recent sediments provide a model that can help us deduce the history of a stratigraphic sequence. An understanding of the sedimentary processes operating in the saline lakes of the Great Plains requires knowledge of several basic elements. Our long-term approach to saline lake sedimentology is organized around these elements as follows: (a) description of mineral distribution and sediment patterns observed in 'representive' lakes; (b) determination of the rates of clastic deposition and the factors controlling detrital sedimentation; (c) quantitative documentation of the aqueous and mineral reactions that are occurring; and (d) establishment of the reaction mechanisms and kinetics involved. We are gradually approaching a better understanding of (a) and (b) through field observation and sampling. However, more detailed laboratory studies are required to elucidate the basic chemical reactions and rates.

A number of the processes discussed above and some not listed in this paper have, to date, been inadequately investigated. Specifically, the following studies are needed before a predictive depositional model can be generated and applied to the lacustrine stratigraphic sequence in the basins:

(a) Investigation of the authigenic mineral phases and pore water geochemistry. Identification of these authigenic components is difficult because they are often identical to detrital and endogenic phases and are usually present only in small amounts. Nonetheless, authigenesis and diagenesis of both sulfate and silicate minerals likely play an important role in controlling the chemistry of the brine.

(b) More detailed documentation of the sediment, water and solute budgets of the basins is required. With the possible exceptions of the Quill lakes, Old Wives lake and Devils Lake basins, we do not have an acceptable data base for quantitative assessment of basic flux parameters or residence times. 
(c) The rate and type of organic sedimentation should be determined with particular emphasis on the preservation potential and early diagenesis of this material.

(d) The temporal aspects of the lake sediments must be established using both absolute dating methods and relative chronology. This is of particular importance in resolving the cycle of rhythmites in perennial lakes and the time span needed to accumulate thick $(>40 \mathrm{~m})$ sections of evaporites underlying present-day playas.

\section{Acknowledgements}

Our sedimentological investigation of saline lakes of the northern Great Plains is supported by grants from the Max Bell Foundation, Natural Sciences and Engineering Research Council of Canada, University of Manitoba, and Canadian Plains Research Center. This support is gratefully acknowledged. Preliminary versions of the manuscript were improved by the helpful suggestions of L. Slezak and P. Kilham.

\section{References}

Al-Droubi, A. B., Fritz, B., Gac, J. Y. \& Tardy, Y., 1980. Generalized residual alkalinity concept; application to prediction of natural waters by evaporation. Am. J. Sci. 280: 560-572.

Bell, H.S., 1942. Density currents as agents for transporting sediments. J. Geol. 50: 512-547.

Callender, E., 1968. The postglacial sedimentology of Devils Lake, North Dakota. Ph.D. Thesis, Univ. N. Dakota, $312 \mathrm{pp}$.

Christiansen, E. A., 1967a. Collapse structures near Saskatoon, Saskatchewan, Canada. Can. J. Earth Sci. 4: 757-767.

Christiansen, E. A., 1967b. Preglacial valleys in southern Saskatchewan. Sask. Res. Coun., Map 3, pp.

Christiansen, E. A., 1971. Geology of the Crater Lake collapse structure in southeastern Saskatchewan. Can. J. Earth Sci. 8: $1505-1513$.

Christiansen, E. A. \& Whitaker, S. H., 1971. Glacial thrusting of drift and bedrock. In: Legget, R. F. (ed.), Glacial Till. R. Soc. Can., spec. publ. 12, Ottawa: 121-130.

CNC/1HD (Canadian National Committee for the International Hydrologic Decade), 1978. Hydrologic Atlas of Canada, Fisheries and Environment Canada, Ottawa, 34 pp.

Cole, L. H., 1926. Sodium sulfate of western Canada. Occurrence, uses and technology. Can. Dep. Mines Publ. 646, $155 \mathrm{pp}$.
Dean, W. E., 1981. Carbonate minerals and organic matter in sediments of modern north temperate hard-water lakes. In: Ethridge, F. G. \& Flores, R. M. (eds.), Recent and Ancient Nonmarine Depositional Environments: Models for Exploration. Soc. Econ. Paleon. Min., Spec. Publ. 31: 213-232.

Dean, W. E. \& Gorham, E., 1976. Major chemical and mineral components of profundal surface sediments in Minnesota lakes. Limnol. Oceanogr. 21: 259-284.

Eugster, H. P. \& Hardie, L. A., 1978. Saline lakes. In: Lerman, A. (ed.), Lakes: Chemistry, Geology, Physics. SpringerVerlag, N.Y.: 237-293.

Forel, F. A., 1885. Les ravins sous-lacustre des fleuves glaciaires. C.r. Acad. Sci. Paris 101: 725-728.

Gilbert, G. K., 1885. The topographic features of lake shores U.S. Geol. Surv. Annu. Rep. 5: 75-123.

Golterman, H. L., 1977. Interaction Between Sediments and Freshwater. Junk, The Hague, Neth., 473 pp.

Grossman, I. G., 1949. The sodium sulfate deposits of western North Dakota: a progress report. N. Dakota Geol. Surv. Rep. Invest. I, 65 pp.

Grossman, I. G., 1968. Origin of sodium sulfate deposits of the northern Great Plains of Canada and the United States. U.S. Geol. Surv. prof. Pap. 600-B: B104-B109.

Hakanson, L., 1977. The influence of wind fetch and water depth on the distribution of sediments in Lake Vanern, Sweden. Can. J. Earth Sci. 14: 397-412.

Hammer, U. T., 1978a. The saline lakes of Saskatchewan. 1. Background and rationale for saline lakes research. Int. Revue ges. Hydrobiol. 63: 173-177.

Hammer, U. T., 1978b. The saline lakes of Saskatchewan. 3. Chemical Characterization. Int. Revue ges. Hydrobiol. 63: 311-335.

Hammer, U. T. \& Haynes, R. C., 1978. The saline lakes of Saskatchewan. 2. Locale, hydrography and other physical aspects. Int. Revue ges. Hydrobiol. 63: 179-203.

Hammer, U. T., Haynes, R. C., Lawrence, J. R.\& Swift, M. C., 1978. Meromixis in Waldsea lake, Saskatchewan. Verh. int. Ver. Limnol. 20: 192-200.

Hardie, I. A., Smoot, J. P. \& Eugster, H. P., 1978. Saline lakes and their deposits: a sedimentological approach. In: Matter, A. \& Tucker, M. E. (eds.), Modern and Ancient Lake Sediments. Blackwell Scientific Publications, Oxford: 7-41.

Handford, C. R., 1982. Sedimentology and evaporite genesis in a Holocene continental sabkha playa basin - Bristol Dry Lake, California. Sedimentology 29: 239-254.

Haynes, R. C. \& Hammer, U. T., 1978. The saline lakes of Saskatchewan. 4. Primary production of phytoplankton in selected saline ecosystems. Int. Revue ges. Hydrobiol. 63: 337-351.

Jones, B. F. \& van Denburgh, A. S., 1966. Geochemical influences on the chemical character of closed lakes. In: Symposium of Garda, Hydrology of Lakes and Reservoirs, Proc. int. Ass. Sci. Hydrol. Publ. 70: 438-446.

Kelts, K. \& Hsü, K. J., 1978. Freshwater carbonate sedimentation. In: Lerman, A. (ed.), Lakes: Chemistry, Geology, Physics, Springer-Verlag, N.Y.: 295-323.

Langham, E. J., 1970. Interim report and program review of the Big Quill Lake study. Rep. E 70-12, Sask. Res. Coun., Saskatoon, $39 \mathrm{pp}$. 
Lawrence, J. R., 1978. Factors influencing the contribution of Chlorobacteriaceae to primary production in a saline meromictic lake. M.Sc. Thesis, Univ. Saskatchewan, 103 pp.

Lawrence, J. R., Haynes, R. C. \& Hammer, U. T., 1978. Contribution of photosynthetic green sulfur bacteria to total primary production in a meromictic saline lake. Verh. int. Ver. Limnol. 20: 201-207.

Lee, G. F., 1970. Factors affecting the exchange of material between water and sediments. Univ. Wis. Wat. Res. Center, Lit. Rev. 1: 1-50.

Lieffers, V. J., 1981. Environment and ecology of Scirpus maritimus L. var. paludosus (Nels.) Kük. in saline wetlands of the Canadian prairies. Ph.D. Thesis, Univ. Manitoba, 167 pp.

Meneley, W. A., Christiansen, E. A. \& Kupsch, W. O., 1957. Preglacial Missouri River in Saskatchewan. J. Geol, 65: 441-447.

McKay, G. A.\& Stichling, W, 1961. Evaporation computations for Prairie reservoirs. Proc. Hydrol. Symp. 2, Evaporation. Queen's Printer, Ottawa, $180 \mathrm{pp}$.

Müller, G., Irion, G. \& Forstner, U., 1972. Formation and diagenesis of inorganic $\mathrm{Ca}-\mathrm{Mg}$ carbonates in the lacustrine environment. Naturwissenschaften 59: 158-164.

Müller, G. \& Wagner, F., 1978. Holocene carbonate evolution in Lake Balaton (Hungary): a response to climate and impact of man. In: Matter, A. \& Tucker, M. E. (eds.), Modern and Ancient Lake Sediments: Blackwell Scientific Publications, Oxford: $57-81$.

Murphy, D. M.\& Wilkinson, B. H., 1980. Carbonate deposition and facies distribution in a central Michigan marl lake. Sedimentology 27: 123-136.

Prest, V., 1970. Quaternary geology of Canada. In: Douglas, R. J.W. (ed.), Economic Geology and Minerals of Canada, Geol. Surv, Can. Econ. Geol. Rep. 1; 676-764.

Rawson, D. S. \& Moore, G. E., 1944. The saline lakes of Saskatchewan. Can. J. Res. D 22: 141-201.

Reeves, C. C. Jr., 1968. Introduction to Paleolimnology. Elsevier, Amsterdam, 228 pp.

Reeves, C. C. Jr., 1978. Economic significance of playa lake deposits. In: Matter, A. \& Tucker, M. E. (eds.), Modern and
Ancient Lake Sediments: Blackwell Scientific Publications, Oxford: $279-290$.

Rueffel, P. G., 1968. Development of the largest sodium sulphate deposit in Canada. C.1.M. Bull. 61 (678): 1217-1228.

Sly, P. G., 1978. Sedimentary processes in lakes. In: Lerman, A. (ed.), Lakes: Chemistry, Geology, Physics. Springer-Verlag, N.Y.: 65-89.

Sly, P. G., 1973. Sediment processes in Great lakes. In: Proc. Hydrol. Symp. Fluvial Processes and Sedimentation, Univ. Alberta, Nat. Res. Coun. Can., Ottawa: 465-492.

Stalker, A., 1961. Buried valleys in central and southern Alberta. Geol. Surv. Can. Pap. 60-32, 13 pp.

Sturm, M. \& Matter, A., 1978. Turbidites and varves in Lake Brienz ( $S$ witzerland): deposition of clastic detritus by density currents. In: Matter, A. \& Tucker, M. E. (eds.), Modern and Ancient Lake Sediments. Blackwell Scientific Publications, Oxford: 147-168.

Teller, J. T., Bowler, J. M. \& Macumber, P. G., 1982. Modern sedimentation and hydrology in Lake Tyrrel, Victoria. $J$. Geol. Soc. Aust. 29: 159-175.

Tomkins, R. V., 1953. Magnesium in Saskatchewan. Sask. Dep. Min. Resour., Rep. 11, 23 pp.

Tomkins, R. V., 1954. Natural sodium sulfate in Saskatchewan (2nd ed.). Sask. Dep. Min. Resour., Rep. 6, 71 pp.

Tones, P. I. \& Hammer, U. T., 1975. Osmoregulation in Trichocorixa verticalis interiores Sailer (Hemiptera, Corxidae) an inhabitant of Saskatchewan saline lakes, Canada. Can. J. Zool. 53: 1207-1212.

Weisman, W. 1.\& Tandy, C. W., 1975. Sodium sulfate deposits. In: Lefond, S. J. (ed.), Industrial Minerals and Rocks, 4th ed. AIME. N.Y.: 108I-1093.

Wetzel, R. G., 1975. Limnology. W. B. Saunders Company, Philad., Pa., 743 pp.

Whiting, J. M., 1974. Closed drainage lakes are a climatic change indicator. Sask. Res. Coun. Rep. E74-10, 31 pp.

Wigley, T. M. L., 1977. WATSPEC: a computer program for determining the equilibrium speciation of aqueous solutions. Br. Geomorph. Res. Group tech. Bull. 20, 48 pp. 